Cinémas

Revue d'études cinématographiques

Journal of Film Studies

\title{
Document : Letter to Ivor Montagu
}

\section{Sergueï M. Eisenstein}

Volume 11, numéro 2-3, printemps 2001

Eisenstein dans le texte

URI : https://id.erudit.org/iderudit/024847ar

DOI : https://doi.org/10.7202/024847ar

Aller au sommaire du numéro

Éditeur(s)

Cinémas

ISSN

1181-6945 (imprimé)

1705-6500 (numérique)

Découvrir la revue

Citer cet article

Eisenstein, S. M. (2001). Document : Letter to Ivor Montagu. Cinémas, 11(2-3),

69-70. https://doi.org/10.7202/024847ar d'utilisation que vous pouvez consulter en ligne.

https://apropos.erudit.org/fr/usagers/politique-dutilisation/ 


\section{DOCUMENT \\ Letter to Ivor Montagu ${ }^{1}$}

\section{Sergueï M. Eisenstein}

Dear Ivor!

Many thanks for your letter. Let us publish "Montage 1938" in "Life and Letters to-day" and make all the arrangements with the translator you think reasonable.

Get in touch with the "Life and Letters" people.

I'm sending them also a line about it.

There are a few changes in the article I want to make for the english version: you will find them inclosed here: $I$ think it advisable to add to the examples taken from Poushkin - some bits of Keats, Shelley and Milton ${ }^{2}$.

I've made notices on them where to place them and what to barr out of the original russian text. I hope that the notes are clear enough and will be very thankfull for your supervising of the translation.

I'm not sure yet about my visit, but will let [you] know at once. I'll be very glad to see your picture and want to have news about everyhing you're doing.

I am working on the script of "Frunze", which deals with the defeat of General Wrangel in the Crimea in 1920. The author is A. Fadeev, whose book "Razgrom" ${ }^{3}$ you surely must know ${ }^{4}$.

My best regards to Hell, Sidney and Jack.

With all my love. Yours

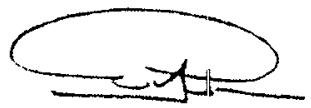

Moscow

April 18th 1939 
N.B. Do you need any books from here, or anything special? Let me know about it and I'll send you everything.

Notes : François Albera

\section{NOTES}

1. Cette lettre d'Eisenstein à Ivor Montagu m’avait été aimablement communiquée par ce dernier dans les années quatre-vingt.

2. La lettre était accompagnée d'une dizaine de pages de citations de ces poètes anglais à substituer aux extraits de poètes russes dans le texte original. Les différences qui apparaissent entre les deux versions sont donc des variantes dues à Eisenstein et non des "ajouts de Jay Leyda ", l'éditeur de The Film Sense, comme l'affirme Armand Panigel à plusieurs reprises dans l'édition française (1976a, p. 240, note 26, p. 242, note 30 , p. 241, note 31) tandis que Richard Taylor suggère que "le traducteur a choisi les exemples dans la poésie anglaise avec l'autorisation d'Eisenstein "(1991a, p. 416, note 333). On connait quatre versions en russe de "Montage 38 " conservées dans les Archives d'Érat (1923/1/1180-6), la première publiée dans Iskousstvo kino, n"1, janvier 1939, la quatrième dans le traité de L. Kouléchov, Les Fondements de la réalisation cinématographique (Moscou, 1941), sur laquelle s'est basée l'édition anglaise des Selected Works (1991a).

3. Razgrom (La Défaite), ce livre de A. Fadeev, publié en 1927, conte un épisode de la guerre civile situé en Extrême-Orient en 1919 dans lequel un bataillon de l'Armée rouge résiste hérö̈quement jusqu'au dernier.

4. Sur ce projet de film non réalisé et sur les rapports, dès 1923, d'Eisenstein avec Frounzé, héros de la guerre civile, voir son texte, légèrement antérieur à cette lettre, paru dans Kino le 23 février 1939, "Pérékop " (1974, p. 79-82). 